\title{
カーナビゲーション装置の関連した事故の分析
}

\author{
○田久保 宣晃、木平 真、小島 幸夫（科学警察研究所）
}

The analysis of traffic accidents influenced by in-vehicle navigation devices

Nobuaki Takubo, Makoto Kihira, Yukio Kojima(National Research Institute of Police Science)

1. 緒言:近年、カーナビゲーション装置(以下カーナ ビ装置)の普及が急激に進んでおり、その累計出荷台 数は約 700 万台に達している。カーナビ装置の使用 は、従来の紙地図や案内標識に対寸る脇見の減少、 経路を決定する精神的負荷の減少、等の利点があると されている。その一方で、カ一ナビ装置の操作と情報 取得のための脇見や精神的負荷の增加等の課題が新 たに生じる可能性があり、装置の適切な設置位置、作 業時間と操作手順、等の人間工学的な検討が各方面 でなされている。検討の多くは、実験的な環境下でな されているが、カーナビ装置が現実の交通場面で運 転者にどのような影響を与えているか在検証することも 重要と考えられる。本稿では、カーナビ装置の影響し た交通事故を、装置の影響の顕在化した結果の一部と 位置付け、二種類の事故データを元にした分析によっ て、事故の発生状況の傾向 (既報 ${ }^{(1)}$ で一部報告済み) と、事故例にみられる発生要因の特徽について検討し た結果を報告する。

2. 方法:本稿では二種類のデータを分析する。

(1)統計分析: 警察庁の管理する交通事故統計データ を統計的傾向の分析に用いた。同データは、警察に 報告された交通事故のうち人身傷害が伴う事故につい て作成され(個人情報孝除く)、事故地点の道路環境状 況、当事者の属性、車両の特徽、等の約 100 項目に 関するデー夕を含む。本稿では、平成 11 年中のデー タベース(約 85 万件)を対象とし、そのうち、カ一ナビ 装置が影響したと判断された事故(以下ナビ事故)は 219 件であった。

(2)事故例分析:ナビ事故のうち、代表的、特徽的と判 断した事故について、より詳細な事故状況に関するデ 一夕(個人情報を除く)を事故例分析に用いた。

3. 統計的傾向の分析: 図 1 に事故の第 1 当事者の 車種を、全事故とナビ事故とで比較して示寸。普通乘 用車がナビ事故の約 $92 \%$ 占めるのに刘儿、全事故 では約 58\%に過ぎない。母集団の著しい差異を避け るため、以下の分析では、当事者を普通乘用車に限定
する(ナビ事故 201 件、全事故 491,946 件)。

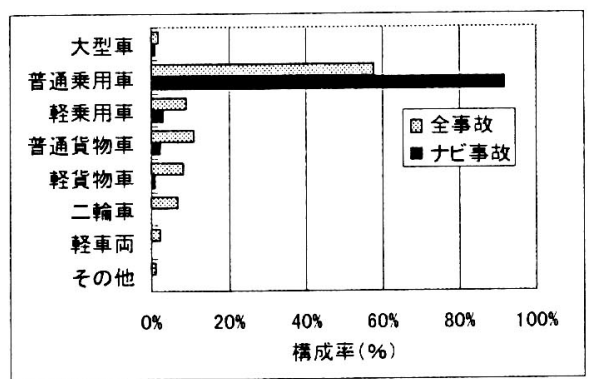

図1 第1当事者の車種別構成率

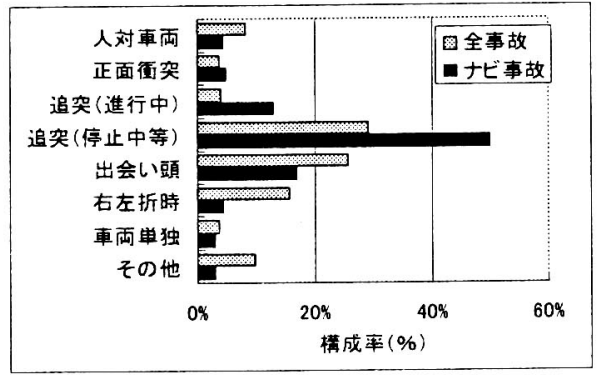

図2 事故類型別構成率

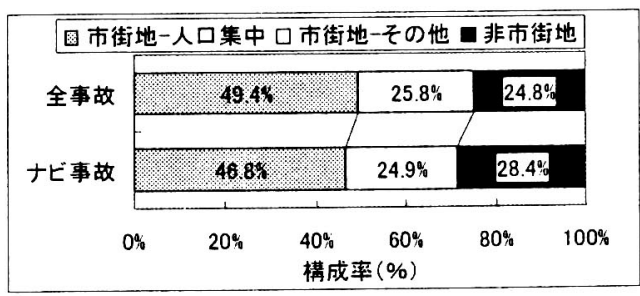

図3 発生地点別蔧成率

全事故の傾向と比較したナビ事故の主な特徽を挙げ る(図2〜図7、一部の特徽は文章のみ)。

- 事故類型:追突事故が多〈なり、右左折事故や出会 い頭事故が少ない。

・発生地点:市街地での事故が少ない。交差点での 事故、小幅員道路での事故も少ない。

- 発生時:夜間の事故が多く、全体で見られる午前中 のピークはない。日曜や土曜、さらに、休日やお盆 といらた非平日に多い。 
・当事者:若年層が多く、高齢者は少ない。観光やド ライブ目的の私用での走行が多い。危険認知速度 の傾向から、より高速での事故が多い

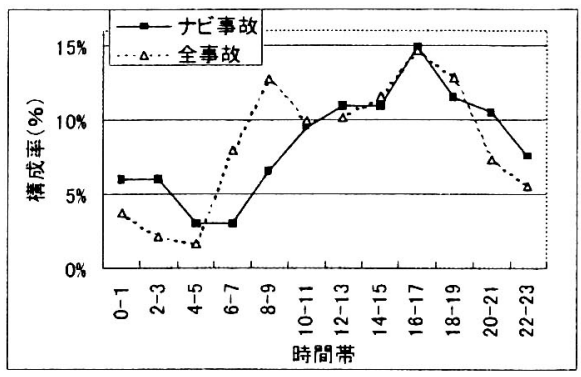

図4 発生時間帯別棈成率

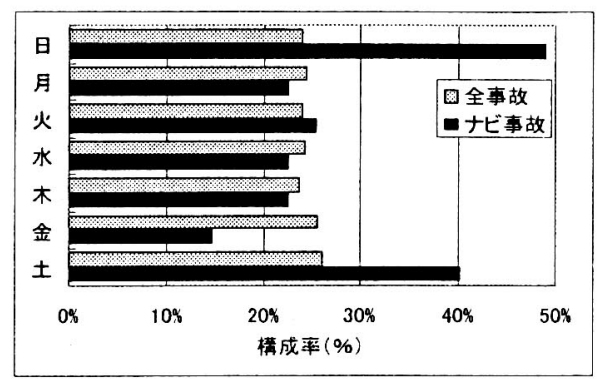

図5 発生曜日帯別構成率

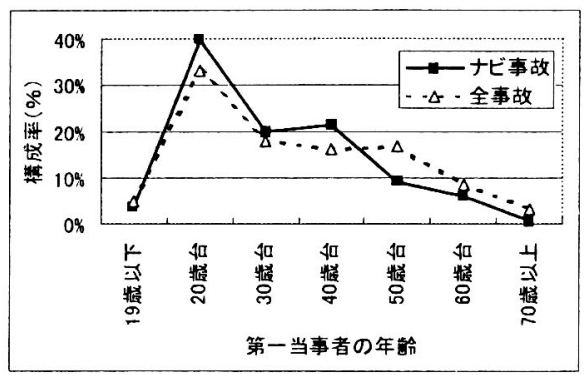

図6 第1当事者の年齢別構成率

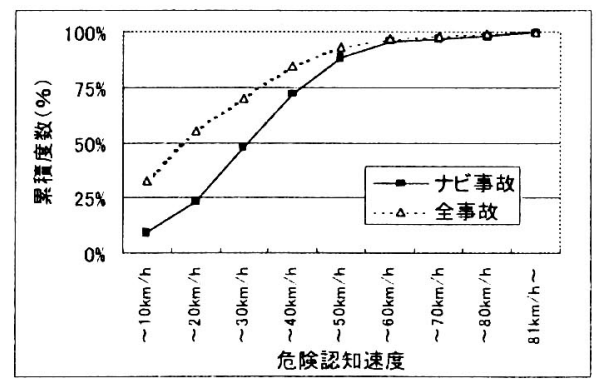

図7 危険認知速度別の满成率

4. 事故例分析: 最屯多い形態である追突事故例亡、 その他の例として正面㣫突事故例圭例示寸る。

4-1. 追突事故(図8): 発生は、「8月・土曜日・午後9時・ 啨れ」。発生場所以、「高速道路・片側二車線で中央分 離带有・直線の下り公配・交通は混雑」。走行目的之土
地勘は、「不明」カカービ装置の設置位置は「助手席側 (徭付け)」。事故の経緯は、「高速道路を前車(ア)に追 従して走行中(1)、車内左側(助手席前)の力一七゙装置 に脇見をしながら $60 \mathrm{~km} / \mathrm{h}$ で進行した(2)）。前方に視 線を戻したところ(3)、渋滞で停止した前車(价に気付 き、急制動したが追突した(4)、ウ)」㴀滞の発生も予想 される状況下での注視であった。

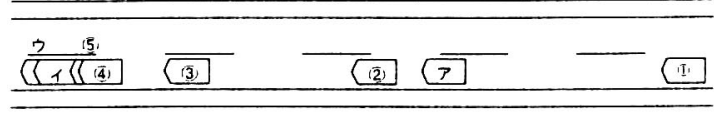

図8 追突事故例

4-2.正面衝突事故(図9):発生は、「9月・火曜日・午前 10 時・小雨」。発生場所は、「国道・往復二車線·左力一 プ・交通は閑散」走行目的と土地勘は、「初好て 上 地でのドライブ(観光)」。か一七゙装置の設置位置は、「セン ターコンソールの中央部(純正)」。事故の経緯は、「力十七 装置を操作するため左下方に脇見をしリモコンを持っ た(1)。同乗者の声で前方に視線を戻したところ(2))、 自車が中央線を超えていることに気付き、同時に直前 の対向車(ア)を発見し、急ブレ一キをか外たが間に合 わず偅突した((3)、亿)。脇見中の車両運動と、それによ り生じる可能性のあるコース誤差を予測できていない。

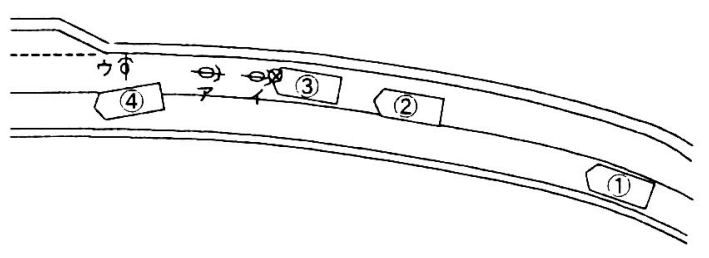

図9 正面衝突事故例

\section{5. 結言:}

カーナビゲーション装置の影響した交通事故の傾向と 特徽老分析した。事故の傾向は、カーナビ装置の利用 者層や利用状況(場所・時)等の影響を大きく受けてい る事がわからた。また、事故の特徽では、通常の事故 の発生経緯と比較して大きく異なるか否かは判断でき ないものの、安全とはいえない走行状況下でカーナビ 装置が脇見の誘引となっていることが確認できた。今 後も同装置や他のITS 装置の影響した事故の分析を 継続する予定である。

\section{参考文献}

1) 田久保宣晃、西田泰: 車載情報機器と交通事故、 人間工学 36 特別号、148-151、2000. 